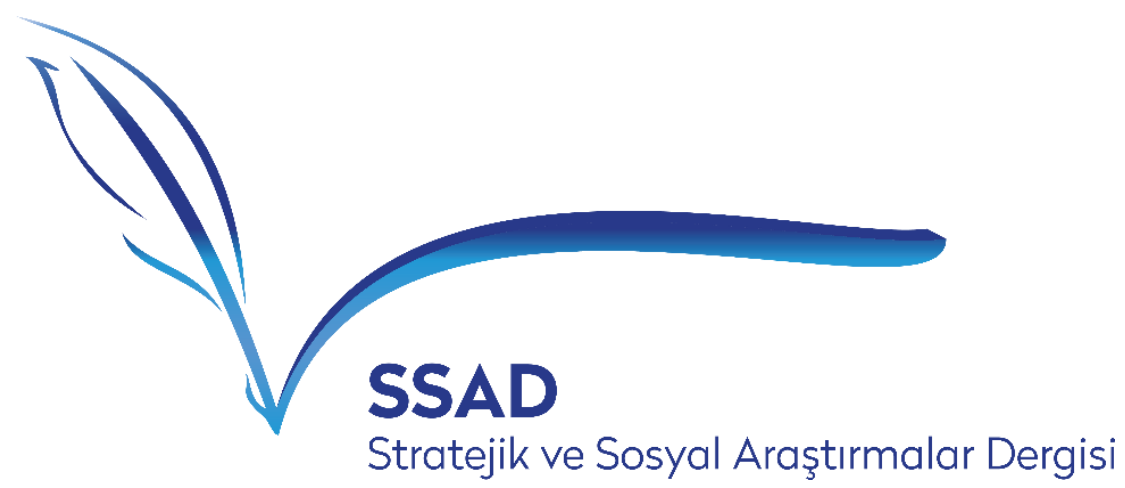

ISSN : 2587-2621

Volume 3 Issue 3, November 2019

ORCID ID: 0000-0002-9617-3787

Makale Gönderim Tarihi: 29.08.2019

Makale Kabul Tarihi: 18.10.2019

GÖÇMEN VE SINEMA AVRUPA GÖÇMEN SIINEMASI ve TÜRK ASILLI YÖNETMENLER

\author{
Migrant and Cinema \\ European Migration Cinema and Turkish Directors
}

\title{
Yelda ÖZKOÇAK
}

\author{
Doç. Dr. \\ Doğuş Üniversitesi, \\ Fen Edebiyat Fakültesi, İletişim Bilimleri \\ yozkocak@dogus.edu.tr
}

Öz: Tarihsel bir dönemi, toplumsal koşulların içinde gerçekleşen bir olayı ifade eden göç'ü, kökeni insanlık tarihinin başlangıcına kadar uzanan, farklı biçimlerde gerçekleşebilen bir kavram olarak açıklamak mümkündür. Göçmen ise içinde bulunduğu koşullar neticesinde kendi ülkesinden ayrılan başka bir ülkeye, o ülkenin bilgi ve izni ile yerleşen kişiyi tanımlamaktadır.

Farklı dönemlerde gerçekleşmiş olan göç olayları ile birlikte, göç alan ülkelerin ve göç edenlerin aydın ve sanatçıları edebiyat, sinema gibi sanatın çeşitli alanlarında ortaya koydukları eserlerinde göçü ve göçmenleri anlatmaya çalışmışlardır. 
Toplumsal gerçekliğin, yaşanan olayların içinde yer alan sinema, içinde bulunduğu toplumsal yapı çerçevesinde, toplumsal gerçekliği yeniden üreten kültürel temsilleri aktarırken göç olgusunu da irdelemektedir. Göçün ve göçmenliğin ne olduğu, ortaya çıkma nedenleri ve eylemin ortaya çıkardığı sonuçlar, göçmenlerin sosyo-ekonomik ve psikolojik durumları yeni görme ve düşünme biçimleri ile film dili aracılığıyla ortaya konulmaktadır.

Türk sineması bağlamında, özellikle İkinci Dünya Savaşı sonrası işgücü gereksinimini karşılamayı hedefleyen Avrupa'ya (demografik yapısını değiştirerek) göç eden Türklerin hikâyelerini anlatan filmler yapılmıştır.

Bu çerçevede çalışmada daha önce yapılmış olan araştırmalardan ve kuramcıların bakış açılarından faydalanılarak, göç ve göçmenlik kavramları ile göçmen sinema tanımlanmaya çalıșılmış, son bölümde ise Türkiye'den Avrupa'ya göçen ve gittikleri ülkelerde yönetmen olarak göçün ve göçmenlerin konu alındığı filmler gerçekleştiren aslı Türk olan yönetmenler ele alınmıştır.

Anahtar kelimeler: Göç, Avrupa Göçmen Sinemas1, Türk Yönetmenler

\begin{abstract}
It is possible to explain a historical period, migration, which expresses an event taking place in social conditions, as a concept that can be realized in different ways, whose origins go back to the beginning of human history. Immigrant can be defined as a human condition for the individual who leaves his / her own country as a result of his / her conditions.

When the history of the world is examined, together with the migration events that took place in different periods, the intellectuals and artists of the countries and the immigrants tried to explain the migration and the immigrants in their works in various fields such as literature and cinema.

Cinema, which takes place in the events of social reality and events, examines the phenomenon of migration while conveying cultural representations that reproduce social reality within the framework of its social structure. What immigration and immigration are, the reasons for the emergence and the consequences of the action are presented through the new language of seeing and thinking about the socio-economic and psychological situations of immigrants and the language of film.

In the context of Turkish cinema, films were made about the stories of the Turks who migrated to Europe (changing their demographic structure), which aimed at meeting the labor force requirement after the Second World War.

In this context, migration and immigration concepts and immigrant cinema will be tried to be defined by making use of previous researches and theorists' perspectives. The last part of the immigration and migration from Turkey to Europe as a director in the countries they go and perform original movies that received migrant issues are discussed with the Turkish director.
\end{abstract}

Keywords: Migration, European Migration Cinema, Turkish Directors

\title{
GíRiș
}

Ekonomik, toplumsal ve/veya siyasi sebeplerle bireylerin, toplulukların bir ülkeden başka bir ülkeye, bir yerleşim yerinden başka bir yerleşim yerine gitmesi olarak tanımlanan göç, kısaca yaşam yerini değiștirmek anlamına gelmektedir (TDK, 2018). Ana Britanica ise göçü, bireyin yeni koșullara daha iyi uyum sağlayabilmek amacıyla ya da doğal, ekonomik, siyasal vb. zorunluluklar sonucunda yaşadığı topluluğu değiş̧irmesi olarak tanımlamaktadır (Cilt 13, s.414).

Göç olgusu sadece bireylerin/toplumların bir yerden başka bir yere gitmeleri olarak anlaşılmamalıdır. Özer'e göre bu eylem genel olarak değerlendirildiğinde toplumu, sosyal, ekonomik, kültürel, siyasi ve psikolojik olarak değiştirmektedir (2004, s.11) ve Tekeli'nin de değindiği gibi göç süreci, çeşitli uyum sorunlarını da beraberinde getirmektedir (2008, s.173-174).

Savaşlar, darbeler, toplumsal hareketler, ekonomik koşullar, siyasi yaklaşımlar insanları göç eylemine sürüklemekte, insanlar doğdukları yerden, şiddetten, baskıdan kurtulmak ya da daha iyi bir hayat için ayrılmaktadır. Göç olgusu, uzun yıllardır farklı bakış açıları ve nedenlerle birçok alanda 
tartış1lmaktadır. Çalışmalara göre, göçün ve göçmenliğin; ulusal kimlik, din, dil, kültür, ekonomik, politik, sosyal, psikolojik ve kültürel bağlamda hem olumlu hem de olumsuz etkileri vardır.

Coğrafyacı ve harita uzmanı Georg Ravenstein "Göç Yasaları" başlıklı makalesinde yedi tane kanun üzerinden göç olgusunu açıklamaktadır (Ravenstein, 1885, s.198-199 aktaran Unat, 2002, s.4):

- Göçmenlerin büyük çoğunluğu yakın yerlere göç ederler. Göç edilen bölgeler genelde sanayileşmenin yoğun olduğu yerlerdir.

- Kentlerdeki sanayileşme/ekonomik gelişme, kentin yakınındaki kırsal alanlardan göçmenlerin kente göç etmesinde etkilidir. Küçük yerleşim yerlerindeki nüfus yoğunluğunun azalması diğer bölgelerden gelen göçmenler tarafindan engellenir.

- Göç hareketlerindeki yayılma süreci kentin getirilerinden yararlanmak isteyen göçmen tarafindan desteklenirken hızla gelişmekte olan sanayinin ihtiyaç duyduğu işgücü ile karşılaşır ve böylece gelen göç, kentsel sanayi merkezlerince emilir.

- Her göç dalgası bunu karşılayan karşı dalga yaratır. Yoğun göç alan yerleşim merkezleri aynı zamanda göç de verir.

- Uzun mesafeye göç edenler daha çok büyük ticaret ve endüstri merkezlerini tercih etmektedirler.

- Kent yerlileri, kırsal kesim yerlilerine oranla daha az göç etme eğilimindedirler.

- Kadınlar erkeklere göre daha fazla göç eğilimi taşırlar.

Bir diğer araştırmacı William Petersen, Göçün Genel Tipolojisi adlı makalesinde basit olarak göçü dört tipe ayırmıştır:

- İlkel göç,

- Zorlama ile yapılan göç,

- Bireyin kendi tercihleriyle gerçekleştirdiği serbest göç

- Kitlesel göçler (aktaran Yalçın, 2004, s.14-16).

Akrabalık, dostluk ilişkileri, benzer kültürler, ortak kökenler, eski göçmenler, yeni göçmenler ve göçmen olmayan kişiler arasında göç hareketini özendirici bağların kurulmasını sağlamaktadır. $\mathrm{Bu}$ kişiler arası bağların varlığı, yeni bir iş bulmak, yardımlaşmak ve sosyalleşmek konusunda başvurabilecekleri bir toplumsal değer olarak ortaya çıkmaktadır. Yeni bir hayat hedefiyle başka bir ülkeye göç eden ilk göçmenler için, göç hareketinin hiçbir sosyal bağlantısının olmaması, yaşama düzeninin tamamen değişmesi gibi sebeplerle hem maddi hem de manevi açıdan oldukça masraflı bir süreç olduğu vurgulanmaktadır. Ancak, bu zor süreci aşan göçmenleri izleyen yeni göçmenlerin arkadaşlık ve akrabalık bağlarına dayanarak daha düşük masraflarla göç edebildiğini ve bu durumun göçü sürekli hâle getirdiği belirtilmektedir (Massey vd. 1993, s.444-445).

Jeff Crisp ise (2006, s.6-7) göçleri, etkilerini ve işleyişlerini dört madde üzerinden açıklamaktadır:

- İlk etki bilgiye yöneliktir. Kurulan uluslararası göçmen ağı, potansiyel göçmenler için önemli bir bilgi kaynağıdır ve göçe katılacaklar bu bilgi ile desteklenmektedir. 
- İkinci etki, potansiyel göçmenin ülkesinden ayrılıp hedef ülkeye gitme maliyetini karşılama ve bu maliyeti en aza indirmeye odaklıdır.

- Üçüncü etki, illegal göçü artırma ve illegal göçün organizasyonuna zemin hazırlamaktır.

- Dördüncü etki ise gidilen ülkedeki desteğe yöneliktir. Kurulan ağ göçmenlerin ilk gittikleri dönemdeki geçimlerini sağlamakta ve yeni gelenleri bu bağlamda desteklemektedir.

Göç edenlerin ve göç alan yerlerde yaşamakta olan bireylerin kültürlerini değiştiren göç olgusunun nedenlerini Chambers, (2005, s.10 aktaran Şahin, 2001) iki kuramla açıklamaktadır:

Modernleşme ve Gelişme Kuramına göre, bireyler, kendi istekleriyle daha iyi nitelikte olduğuna inandıkları bir yaşam alanına gitmektedirler.

Merkez Çevre İlişkileri Kuramı ise, ekonomik olarak güçlü olan ülkelerin daha vasıfsız işleri üstlenmeleri için, çevre ülkelerle gerçekleştirilen bir insan sirkülasyonunu ifade etmektedir.

Chambers'in savına karşın Şahin göçmenlerin, yeni bir toplumla girdikleri etkileşime ilişkin temelde üç temel kuram bulunduğunu ifade etmektedir. Bunlar; normatif yap1 ve sosyal iletișim örüntülerinden ani kopuşun neden olduğu yalnızlık durumunu belirten Toplumsal Yalıtılma Kuramı, göç edilen ülkede ortaya çıkan kültürel farklar nedeniyle yaşanan uyum sorununa vurgu yapan Kültürel Şok Kuramı ve yeni bir kültüre uyum sağlama sürecinde göçmenlerin yaşadığ 1 gerilime vurgu yapan Kültürel Değişme Kuramı'dır (2001).

Tüm bu tanımlamaların ve kuramsal yaklaşımların yanı sıra Keeley, özellikle göç alan ülkelerde insanların göçmenlere karşı negatif tutum sergilemekte olduğunu ifade etmektedir (2009, s.44). Göç eylemini gerçekleştiren bireyler, yalnız olduğunu düşünme, özlem duyma, yurtsuzluk, aşağılık kompleksine kapılmakta, bir yandan asimile olmaktan korkarken diğer yandan ötekileştirilmek istememektedir.

17. yüzyılda ve öncesinde gerçekleşen göç eylemleri şiddete dayalı ve belli bir emek aktarımı içermemektedir. Buna karşın 18. yüzyılın sonları ve 19. yüzyılın başlarında Amerika kıtasına doğru olan köle ticareti emeğin yer değiştirmesi açısından kendisinden önceki göç hareketlerinden ayrılmaktadır. Bu bağlamda kimi yaklaşımlara göre ulus-devletlerin ortaya çıkışı uluslararası göçün de başlangıcı sayılmaktadır (Tellal, 1994, s.417 ve Krippendorf, 1975, s.5 aktaran Çoban,2014).

Yapılan araştırmalar en fazla göç hareketinin Avrupa ülkelerine doğru olduğunu göstermektedir. 1850-1914 arasında birçok Avrupalının Amerika, Avustralya, Yeni Zelanda ve Güney Afrika ülkelerine göç etmesine karşın, özellikle İkinci Dünya Savaşı’nın ardından durum tersine dönmüş, 19. yy boyunca göç veren Avrupa ülkeleri, işgücü açı̆̆ını göçmen işçi anlaşmalarıyla kapamaya çalışmıştır. Ekonomik kalkınmaya destek olduğu için olumlu bir olgu olarak görülen göç, 1960’lı yıllarda Avrupa'nın "konuk-işçi” kabul etmesiyle önemli ölçüde artmıştır. Bu göçlerin bir bölümü savaşın etkilerinden kaçanlar, bir bölümü de zoraki göçe zorlananlardır. Savaş sonrası göç eylemlerinin bir kısmı da mübadelelerle yani yeni sınırların çizilmesi ile olmuştur (Bulgarlarla Romenler, Türklerle Yunanlılar arasındaki mübadele, Alman işgali altında bulunduğu yıllarda çok sayıda Rus'un Cirallar'a ve Orta Asya'ya göç etmesi örnek olarak gösterilebilir). Avrupa'da gerçekleşen ilk kitlesel iş göçü İkinci Dünya Savaşı sonrası İtalya'dan Belçika'ya doğru yaşanmış, 
ardından Almanya ve Fransa'ya yapılan göçler, insanların içinde yaşadıkları coğrafi ve sosyo-kültürel çevreden ayrılarak başka bir mekana gitmesi ile göçmenler hem kendilerini hem de içine girdikleri sosyo-ekonomik çevreyi değişime uğratmıştır. Savaş sonrası sanayileşmeye dayalı olarak artan işçi talebini karşılamak üzere Batı Avrupa ülkeleri, işgücü eksikliklerini göreli olarak daha az gelişmiş olan güneydeki komşu ülkelerden karşılamaya çalışmış, İtalya, Yunanistan, Yugoslavya, İspanya ve Türkiye' den göçler olmuştur (Robins 2007, s. 152, Berghahn and Sternberg, 2010, s.13, Bhatia and Ritchie, 2013, s.71).

Örneğin, 1955-1973 yılları arasında İtalya, İspanya, Yunanistan, Yugoslavya ve Türkiye'den yaklaşık dört milyon göçmen Almanya'ya Gastarbeiter (konuk işçiler) olarak gitmiş, bu göçmenlere aileleri de eklenmiş ve kalıcı diasporik topluluklar oluşmuştur (Berghahn and Sternberg, 2010, s.13). 30 Ekim 1961 tarihinde, Almanya'nın Bonn kentinde Türkiye ile Almanya arasında "İşgücü Alımı Anlaşması" imzalanmıştır. Benzer antlaşmalar, Avusturya, Belçika ve Hollanda ile 1964'te, Fransa ile 1965'te ve İsviçre ile 1967 'de yapılmıştır Daha önceleri "ismen davet" usulü olan işçi göçü bu tarihlerden sonra tamamen ilgili hükümetlerin politikalarına bağlı olarak Türk işçilerin Batı Avrupa'ya göçü 1974 yılına kadar devam etmiştir (Turan, 1997, s.3, Dışişleri Bakanlığı arşivi, 2018).

Türkiye'den yurtdışına yapılan göç, temelde dört biçimde yapılmaktadır. Bunlar; aile ilişkileri vasıtasıyla yapılan göçler, yasadışı düşük yetenekli işçi göçleri, uluslararası profesyonel göçler ve siyasal sığınma olarak sinıflandırılmaktadır (İçduygu, 2006). Türk göçmenlerin önemli bir bölümü ve özellikle 1970 ve 1974 yılları arasında gidenler Türkiye'nin en geri kalmış kırsal bölgelerinin insanlarıdır. Prof Dr Cahit Talas'ın saptamasıyla bu insanların çoğu ana eğitimi yetersiz olduğundan gittikleri ülkelerdeki toplumun yaşam biçimine hemen uyum sağlayamamışlardır (aktaran Makal, 1994, s.59).

Türk işçilerin konuk oldukları ülkenin dilini bilmeme, karmaşık kurallara bağlı olan eğitim sisteminden gereği gibi yararlanamama, farklı bir topluma uyum göstermede zorluk çekme gibi sıkıntıları onları kendi içine kapanmaya doğru itmiștir. Ayrıca hükümetlerin uyguladıkları eğitim politikalarının değişik olmasından dolayı Alman dilinde verilen dersleri anlayamayan çocuklar bir süre, aslında zeka engelli çocuklar için kurulmuş bulunan Sonderschule'lere (özel okul) gönderilmeye başlanmıştır (Turan, 1997, s.3). Tüm bunların yanı sıra 1980'li yıllardan bu yana üçüncü kuşak ile birlikte Batı Avrupa'da Türkler hayatın her alanında giderek daha fazla görünür olmuştur.

Göçmenleri konu edinen yapitlar/çalışmalar içinde özellikle sinema göçmenlerin sesi olmuştur. Sanatsal özellikleri ve daha fazla kişiye ulaşabilme niteliği sayesinde sinema göçmenlerin yaşadıklarını anlatmada önemli bir araç konumundadır.

Bu bağlamda çalışmada Türkiye'den Avrupa'ya göçen ve gittikleri ülkelerde yönetmen olarak göçün ve göçmenlerin konu alındığı filmler gerçekleştiren aslı Türk olan yönetmenler ele alınmıştır. Çalışmanın bundan sonraki bölümlerinde ikincil kaynaklara bağlı literatür taramasının ardından göçmen, göçmen sineması, Avrupa göçmen sineması ve Avrupa'da yaşayan Türk asılllı yönetmenler, örnekleme bağlı olarak irdelenmiş, hipotez doğrultusunda genellemeler yapılmasına yardımcı olan içerik analizi yönteminden faydalanılmıştır. 


\section{Göçmen Sineması}

Fransız araştırmacı Nejma Monkachi, göçmenlerin, yeni şeyler üretmeleri ve göç edişlerini kendilerine göre anlamlandırmaları gerektiğinden bahsetmektedir. Monkachi’ye göre göçmen, yeni ve eskiden sahip olduğu rol arasında bölünmüşlüğü aynı anda yaşamakta, kendi köklerine dönmekle yaşadığı topluma bağlanmak arasında kalarak bulunduğu toplumda kendisini yeniden üretmeye yönlenmektedir (Monkachi, 2003).

Sinema araştırmacısı Knut Hicketler (aktaran Bilis, 2004, s.59-60) sinema filmlerinde yabanciya dair imgelerin göçmen aracılığıyla aktarılmaya çalışıldığını ve yabancının bilinene dönüştürülmesi ve kategorize edilmesinin dört farklı temsil biçimi ile gerçekleştirildiğine değinmiştir:

- İzleyicinin varlığını tehdit eden ve tehlikeli bir varlık olan yabancının temsili; yabancı temsili ile yeni önyargıların oluşturulması, eski önyargıların ise kuvvetlendirilmesi arzu edilmektedir.

- Hiyerarşik düzende alt basamağa yerleştirilen yabancının temsili; bu kategoride yabancının hiyerarşik düzende içinde yer aldığı ve alt sınıf mensubu olduğunu vurgulayan filmlerdeki temsili kastedilmektedir.

- Egemen düzen tarafından kovalanan ve yardıma muhtaç olan yabancının temsili; bu kategoriye dahil edilen filmlerde yabancı egemen sistem tarafindan kovalanan ve tehdit edilen bir varlık olarak gösterilmektedir. Buradaki amaç izleyicinin duygularına hitap ederek acıma hissi uyandırmaktır.

- Bir komedi unsuru olarak yansıtılan yabancının temsili; yabancı hakkında gülünebildiği sürece hiyerarşinin farklı bir biçimi yaratılmakta ve böylece yabancı tehlikeli bir varlık olarak algılanmamaktadır. Diğeri hakkında gülebilmek, onun üzerinde hâkimiyet kurulabileceğini göstermektedir.

Her eğilimin, çağın toplumsal ve siyasal özelliklerini yansıtan (Rotha 1968, s.341), içinde bulunduğu toplumdan beslenen ve toplumsal gerçekliği yeniden üreten sinemada da göç ve göçmenlerin yaşadıkları süreçler, yaşam koşulları bu açıdan filmlerin konusu olmaktadır. Bu bağlamda, göç olgusunun sinema filmlerinde ele alınması içinde yaşanılan toplumların sosyal, kültürel, ekonomik, politik durumlarının özetini ve yansımasını ortaya koymaktadır. Ulusay, göçmenlerin kültürel pazarlar için bir hedef kitle niteliğinde olduğunu ve onların sorunlarının çok kültürlülük, melezlik gibi konularla birlikte farklı anlatı biçimlerinde filmlere konu olduğunu ifade etmektedir (2008, s.58).

"Modernizmden Postmodernizme Ötekilik" başlıklı çalışmasında Yumul, "Batı, sanat, edebiyat, müzik, mutfak, öğreti ve ritüeller aracılığıyla Öteki'nin egzotik kültürü ile karşılaşır. Tarihten ve bağlamdan soyutlanıp sürekli yeni anlamlar, kimlikler ve aidiyetler peşinde koşan tüketici kültürü için yeniden paketlenen bu ürünler, farklılığı metalaştırıp yüceltiyor" (2000, s.100), sözleri ile ana yurdundan ayrılanların öykülerini anlatan filmlere olan ilginin nedenine açıklık getirmektedir. Bu açıdan göçmen olan ötekinin hikâyesi, kimi sinemacılar tarafindan melez ya da ulus ötesi filmler olarak tanımlanmıştır. Ponzanesi için göçmen sineması tartışmalı bir kavramdır ve yönetmenle bir korelasyon yoluyla "göçmen" etiketinin sınırlamalarını zorlaştırmaktadır (2011, s.74). Farklı nedenlere bağlanan, farklı türlere ayrılan göç olgusu, gerçekliğe yönelik bir kurgu olan sinemada da farklı biçimlerde ifade edilmektedir. 
Kimi sinemacılar tarafindan, Üçüncü Sinema ile benzetilen göçmen (Grassilli, 2008, s.1240) ya da diasporik olarak tanımlanan filmler ulusal ve kültürel sınırları aşan bir konuyu ele aldığında Trifonova'ya göre ulusal sinemalar tarafından üretilen diğer üç film çeşidinden (Amerikan-AvrupaÜçüncü Sinema) küresel bağlamda farklılık göstermektedir (Trifonova, 2018).

Birinci Sinema, Ticari Sinema ya da Hollywood Sineması olarak tanımlanan Amerikan filmleri popüler yapımları ifade etmektedir. Geleneksel anlatı biçimini kullanan bu filmlerin dili kolay anlaşılmaktadır. Burjuva niteliğindeki İkinci sinema ise kendi yapım biçimlerini oluşturan, kendi dağıtım ve gösterim imkânlarını kullanmaktadır. Hollywood sinemasına karşıt olarak ortaya çıkan Üçüncü Sinema ise seyirciyi aktif katılımcı haline getirmek amacında olduğundan, baskı altında olan ve sinemasal egemenliğin ve kuralların geçerli olduğu Batı'ya karşı koyan toplulukların bulunduğu her yerde varlığını göstermektedir (Solanas ve Getino 2000, s.272, Odabaş, 2013, s. 15-20).

Ella Shohat ve Robert Stam, Üçüncü Sinemayı ayrıca üç sınıfa ayırmaktadır. İlk sırada, üçüncü dünya insanlarının kendileri için ürettiği filmler bulunmaktadır. Birinci ve ikinci dünya insanlarının üçüncü dünya insanları tarafindan desteklediği üçüncü sinema örnekleri ikinci grup, mevcut diasporik melez filmleri kapsayanlar ise bu bağlamda üçüncü gruptur (1994, s.27-28).

Göçmen Sinemasının, Üçüncü Sinema kadar somut, tanımlanabilir ve geçerli bir kategori olduğunu ifade eden Yaren, ihmal edildiğini ifade ettiği Göçmen Sinemanın, ulusal sinema paradigmasına benzeyen kimlik farklılıklarına dayalı bir ayrım üzerine biçimlendirilemeyeceğine dikkat çekmektedir (2008, s.11-12). Bu ifadeye karşın, Göçmen Sinemasının, "sürgün", "postkolonyal", "diaspora", "bağımsız ulus-aşırı", "aksanlı", "etnik göçmen" gibi kavramlarla betimlendiği görülmektedir.

Bireyin, yurdundan ya da evinden ayrılmasını ifade eden sürgün sineması, içinde "geri dönme arzusu" olan sürgün bireyi anavatanına doğru ele almaktadır (Kolker, 1999, s.74). Postkolonyal etnik kimlik sinemasının odağı ise sinemacının ait olduğu şimdi ve buradaki ülkenin yaşamı ve gereklilikleri olarak tanımlanmaktadır. Hamid Naficy için bu tür, kimliğin değişim ve dönüşümüyle, odaklandığı yer ile diğer kategorilerden ayrılmaktadır (2014, s.15). Naficy, bağımsız ulus-aşırı sinemanın ise iki ana özelliğini vurgulamaktadır. Bunlar; ana doku içindeki ulus-aşırı (Avrupa ve Amerika'daki üçüncü dünya olarak adlandırılan ülkelerden gelen) yönetmenler ve bu türü karakterize eden klostrofobik mekânların biçimlendirilmesi olarak tanımlanmaktadır (1995, s.36). Sömürge sonrası etnik göçmen gruplar ve kimlik sinemacıları, sürgünün yarattı̆̆1 travmaya, ana yurda, geçmişe değil şimdiki zamana, göç edilen mekanla ilişkiye odaklanmıştır (Naficy, 2014, s.15). Diaspora sineması, anavatanı, ev sahibi ülkeyi ve diğer diasporik toplulukları irdelemektedirler. Sürgün sinemasından farklı olarak, Diasporik sinemacının temsili sadece anavatan üzerine odaklanmıs,, değildir. Naficy'ye göre bu durum diasporik filmlerin sürgün filmlerine göre, çok taraflı bakışlarını daha çok aksanlı hale getirmiştir (2014, s.14). Aksanlı sinema ise bireyin öyküsünü aktaran, etnisite, milliyet, kimlik ve yerinden olma konularını ele alan, politik altyapısı olan, eleștiriye açık ve melez filmlerdir (Rotha ve Griffith, 2001, s.71). Güzel'e göre, aksanlı sinema terimi, Naficy'nin bağımsız ulus-aşırı sinema kavramından gelmektedir. Naficy'e göre, farklı nedenlerle yurtlarını terk etmek zorunda kalan göçmenlerin bağımsız ulus-aşırı filmleri ele aldıkları konular, biçimsel özellikler, bir ya da çoklu dile sahip oluşları, üretim ve tüketim koşulları ile yeni bir tür oluşturmaktadır (aktaran Güzel, 2001, s.42). Bu bağlamda kavram, Batıda yaşayan sürgün, diasporik ya da postkolonyal/etnik kimlikli sinemacıların 1960'lardan bu yana ürettikleri filmleri tanımlamak için kullanılmaktadır. 
Hamid Naficy 2001 yilında yayınlanan An Accented Cinema: Exilic and Diasporic Filmmaking adlı kitabında aksanlı sinemayı tam anlamıyla şöyle tanımlamaktadır:

“Çoğunluğunu, 1960'lardan bu yana, kuzey'in kozmopolit merkezlerinde yerleşmiş ve geldikleri ilk vatanları ve şimdi bulundukları yer arasında uyuşmazlık ve gerilimler yaşayan, üçüncü dünya ülkeleri ve post-kolonyal ülkelerden (ya da küresel güney'den) gelenler genellikle bağımsız, stüdyo sisteminin ya da ana akım film endüstrilerinin dışında çalışırlar. Farklı görülürler ve bu farklılıkların varlığl, aksanlı sinemacıların homojen bir grup ya da bir film hareketi olmalarını engeller. Tüm bu gerilim ve farklılıkları içeren -grupları aksanlı biçemin etkisinde olduğundan-filmler bildik anlatı ve jenerik şemaları ile çözümlenemez. Aksanlı sinemayı oluşturan, bu fark ve benzerliklerin kesişimi ve birleşimidir."

Hamid Naficy bu sinema içinde sinemacıları 1950-1970 arası sömürge sonrasında baş gösteren bağımsızlık hareketleri ve Doğu Avrupa'da gerçekleşen Sovyet müdahaleleri sonrası yer değiştirmelerle kendisini gösterenler ve 1980-1990 arasında yaşanan bir dizi önemli siyasal ve toplumsal dönüşüm sonrasında ortaya çıkanlar olarak ayrıca iki gruba ayırmaktadır (Naficy, 2001, s.10).

Yukarıda değinildiği gibi farklı kelimelerle ifade edilebilen göçmen sinema, kısaca göçmenleri anlatmakta ya da göçmenler tarafından anlatılmaktadır. Ancak temel olarak göç eden sinemacıların yaptığı filmlerle, göçün/göçmenlerin konu alındığı filmleri de birbirinden ayırt etmek gerekmektedir. Bu bağlamda, yönetmeni göçmen olsun ya da olmasın göçün/göçmenlerin konu alındığı filmlerde göçmen sinemanın varlığından bahsedilmektedir. Oğuz Makal'a göre, göç olgusunu temel kurgu malzemesi haline getiren göçmen yönetmenlerde de kuşak farklılığı değişik bakış açılarını beraberinde getirmiştir. Tarihsel olarak ele alındığında, ilk kuşak sinemacılar göçü yaşamış, ikinci ve üçüncü kuşaklar ise ailelerinin deneyimleri üzerine üretimler yapmışlardır (1994, s.63). Ana akım sinemanın dışında, bağımsız, düşük bütçeli olan bu filmlerde yönetmen, filminin her aşamasında yer alabilmekte ve kişisel bakışını ortaya koymaktadır. Ayrıca, Naficy, filmi üreten kişinin, film ekibinin, yönetmenlerin, filmin ele aldığ 1 konunun ve seyircinin çok dilliliğine dikkat çekmektedir (2001, s.4950). Ballesteros'a göre belgesel ve gerçekçi yaklaşım, neredeyse hiçbir göçmen filminde bulunmamaktadır (2015, s.xiii).

Morva'nın da değindiği gibi tüm farklılıklar, ögeler göz önüne alındığında ortak bir tanım yapılması zor olmasına karşın, göçmen sinema, içerik ve biçim açısından oldukça zengin, tek başına bir sınıflandırmayı yaratacak kadar bir film birikimine ulaşmış ve tek başına bir tür olarak sinema alanındaki yerini alarak (2013), Batı dışı geleneklerden kaynaklanan, stil, tür ve formların karmaşık ve eklektik bir karışımını sunmaktadır (Naficy, 2001 aktaran Ponzanesi, 2011, s.74).

$\mathrm{Bu}$ filmler, yaratıcılarının içinde bulunduğu, çifte bilinçlilik durumunu yansıtırlar. Çoğunlukla iki ya da çok dillidirler. Estetik biçimleri homojen değildir. Sinemacıların kendi ülkelerine ve yerleştikleri ülkeye ait sinema geleneklerinin etkisiyle oluşan sinemasal anlatımları vardır (Migrant and Diasporic Cinema in Contemporary Europe, 2014).

\section{Avrupa Göçmen Sineması}

Birinci Dünya Savaşı ile birlikte Avrupa'da toplumsal hiyerarşiler, epistemolojik ve etik dizgeler ve temsil uylaşımları temelden değişmiş, sinema endüstrisi savaştan yüzyılın geri kalan kısmına 
damgasını vuracak kültürel yeni düzenlemenin hem simgesi hem de aracı olarak çıkmıştır. Rus Devrimi ile Fransa'ya, İtalya'ya Almanya ve Çekoslovakya'ya sürgüne gitmek zorunda kalan sinemacılar devrim öncesi Rus sinemasının geleneklerini korumaya çalışarak gerçekleştirdikleri filmler devrim öncesi eserlerin doğrudan tekrarları niteliğinde olmuştur (Nowell-Smith, 2008, s.8594,199-200). Savaşın bittiği 1919 yılından itibaren yaklaşık 20 yıllık süreçte Avrupa ülkelerinde sinema alanında çeşitli arayışlar sonucu farklı anlatı biçimleri ortaya çıkmıștır. Savaștan yenilgi ile çıkan Almanya, insan psikolojisine eğilen dışavurumcu akım ile içine kapanmış toplumun sesini duyurmaya çalışmıștır. Alman sineması gerçeküstü dekor, yapay, abartılı oyunculuklar ile gerçek dünyaya ve mutlu hayata olan özlemi anlatan filmler ortaya koymuștur. Ancak, Nazi döneminde Alman sineması bir propaganda aracına dönüșmüștür. Birinci Dünya Savașı'ndan sonra Mussolini'nin toplumu faşizme göre şekillendirmesinde sinema büyük rol oynamıştır. Faşist İtalyan sinemas1, politik düşüncesini kitlelere yayarken, Nazi Alman sineması gibi propaganda filmleri üretmiştir. 1939 yılında patlak veren İkinci Dünya Savaşı süresince birçok oyuncu, yönetmen, senarist kariyerini sürdürmek için başka ülkelere göç etmek zorunda kalmıştır.

Armat, İkinci Dünya Savaşı sonrası gelişen devrimci coşkunun sinemacıları da içine aldığını ve özellikle 1960'larda ve 1970'lerde birçok sinemacinın çoğu zaman baskı altında veya sürgünde devrimci sinemaya katkıda bulunduğunu vurgulamaktadır (1987, s.88-94). Savaşın hemen ardından İtalyan sineması yeni gerçekçilik akımıyla dikkatleri üstüne çekmiş, Fransa'da yenileşme dönemi Yeni Dalga hareketiyle başlamıştır. Bu yıllarda ilk filmlerini yapan savaş sonrasının ikinci kuşă̆ı, çağdaş toplumu, tarihi çeşitli açılardan sorgulayan filmler gerçekleştirmiş ve özgün anlatı biçimleri geliştirmişlerdir.

Birçok Avrupa ülkesinde yerli popüler filmler, komedi, polisiye ve diğer geleneksel ticari filmlerin yapımı azalmış, izleyici sayısının az olmasına karşın, yeni gerçeklikleri dikkate alan sinema türleri ortaya çıkmaya başlamıştır. Avrupa sineması giderek düşük ve orta düzeylerde sanat sineması ve yüksek bütçelerde ise uluslararası diye nitelenmeye başlanmıştır.

1950 yılından itibaren hızlı sanayileşme sonucunda belli bir ekonomik yapıya ulaşan Avrupa ülkeleri, pazarlarını daha da genişletebilmek için (temelini 1958 Roma Anlaşmasının oluşturduğu) ve işgücü gereksinimini karşılamak amacıyla iş gücü antlaşmaları yaparak göç almaya başlamışlardır. İlk olarak 2.500 Türkün göç ettiği Avrupa'da kültür, artık Batı'nın entelektüel ve kültürel geleneklerinden giderek uzaklaşmaya başlamıştır (Makal, 1994, s.57, Turan, 1997, s.3). Göçmenlerin kimlik oluşumları ve kültürel yaklaşımları ile özellikle Almanya'da yaşayan göçmenler Alman ya da Türk olarak değil, bu ikisinin de üstünde kimliğe sahip olan bireyler olarak ortaya çıkmaktadırlar. Kanbur, bu melez kimliklerin 1990'lar itibariyle güçlenen çok kültürlülük politikalarının da etkisiyle Avrupa sinemasında dikkat çektiğini ifade etmektedir (2005, s.41).

Avrupa'nın işgücü talebini karşılayan “ekonomik bir nesne” olarak Türk göçmen işçiler, etkileri günümüze kadar gelen kültürel bir şok yaşarken, onların varlıkları da Avrupa'nın demografik yapısını değiştirmeye başlamıştır. Ne yaşadıkları ülkenin vatandaşı ne de Türk olabilen özellikle ikinci kuşak ve sonrası göçmenler ilerleyen yıllarda Avrupa sinemasının içinde kendilerine yer bulmuş, sorunlarını, beklentilerini, umutlarını, korkularını yaşantılarını sinema sanatını kullanarak anlatmaya çalışmışlardır.

Ponzanesi, göçmen sinemanın çağdaş Avrupa'yı yeniden canlandıran, çok kültürlü ve çok ırklı merkez mercek odaklarının içinde kendine yer bulmaya çalıştı̆̆ını ifade etmektedir (2011, s.4). Bu bağlamda, göçmen deneyiminin temsili, çağdaş Avrupalı sinemacılar tarafından da ele alınmıştır 
(Ballesteros, 2015, s.17). Göçmen ya da Avrupalı film yapımcıları tarafindan, ulusal kimlik ve "Avrupalılık" kavramlarına meydan okuyan, yeni bakış açılarına göre sınır, dil ve kimlik kavramlarını tekrar gözden geçirerek filmlere yansitılmıştır (Ponzanesi, 2011, s.74).

Böylelikle, Avrupa'daki göçmen sinema iki temel tanıma dayandırılmaktadır:

- Avrupalı olmayan film yapımcıları tarafindan yapılmış filmler;

- Göçmen temalar, karakterler ve konularla ilgilenen filmler (Ponzanesi, 2011, s.75)

Avrupa'da göçmen sinema, öncelikli olarak, Avrupa kimliği ve ulusal kavramlara itiraz eden ve akışkan olan bir varlık durumu olarak ele alan daha geniş sosyo-politik süreçlere odaklanmış (Ponzanesi, 2011, s.74), Avrupa ülkelerinin sinematografik endüstrileri arasindaki farklilıklara rağmen, göçmen sinema, bireysel hayatta kalma stratejilerine odaklanan soyutlamay1 kişiselleştirmiştir (Ballesteros, 2015, s.12). Bağımsız üretilen bu filmler (Naficy 1999) ile Avrupa'daki göçmen sinema, ötekinin sesli ve görsel olarak işlendiğini keşfetmek için ayrıcalıklı bir başlangıç noktası olarak görülmüş, Kanbur'un da değindiği gibi bu filmler, göçmenlerin yaşantılarını aktardığı için aynı zamanda Avrupa sinemasında kimlik temsili sorununa da katkıda bulunmuştur (2005, s.44). 1970-1974 yılları arasında Almanya'ya göçenler, Türkiye'nin geri kalmış kırsal bölgelerinin çoğu eğitimsiz bireyleri (Makal, 1994, s.59) olduğundan Alman sineması 1970'li yıllarda konuk işçi hikâyelerini ele almaya başlamıştır (Işıkoğlu, 2005, s.81). Alman sinemasındaki Türk anlatıları cinsiyet çatışmaları etrafında, iletişimsiz ve uyum sağlayamayan bireyler olarak sunulmuştur. Özellikle Türk göçmen kadınların erkek egemen, feodal, Müslüman ve muhafazakâr Türk toplumunda baskı altında olması, aşağılanması, hatta fahişelikten kurtulması işlenmiştir (Tosun, 2006, s.96). 1990'ların ortalarından itibaren ise Avrupa'da göçmen ya da göçmen kökenli sinemacılar kendi hikâyelerini anlatmaya başlamıştır (Yaren, 2015).

İkinci kuşak Türk göçmen çocukları Almanca'yı öğrenerek öncelikle Alman toplumu ile iletişim kurabilmiş, üçüncü kuşak ise çifte kimlik ve çifte bilinç ile Türklük-Almanlık ikilemini avantaja dönüştürmüştür. Scognamillo'ya göre (2000, s.76) Türkler içinde bulundukları durumlarını, yaşadıkları deneyimleri sinema ile ifade etmişlerdir. Böylelikle ikinci kuşak genç yönetmenler yaptıkları kısa ve uzun metraj film çalışmaları ile isimlerini duyurmuşlardır (Işıkoğlu, 2005). 2000'li yıllara gelindiğinde ise üçüncü kușak ile birlikte göçmen filmleri çeșitlenerek, çok kültürlülüğün avantajlarına vurgu yapan filmler çekilmeye başlanmıștır (Malik, 1996, s.202-215). Almanya'nın ötekileri olarak görülen üçüncü kuşak göçmen Türk yönetmenlerin çektiği filmler katıldıkları uluslararası film festivallerinde aldıkları ödüllerle dikkat çekmiștir. Türk-Alman sineması Almanya'da genel film kültürünü fazlasıyla zenginleştirmiştir. İlk uzun metrajlı filmi Duvara Karşı (Gegen die Wand) ile Berlinale'de En İyi Film (Altın Arslan-2004) ödülünü alan Fatih Akın, Türk asıllı bir yönetmen olarak bu alanda adını geniş bir kitleye duyurmuştur. 


\section{Avrupa'da Yaşayan Türk Asıllı Yönetmenler*}

Dışişleri Bakanlığı'nın verilerine göre; yurt dışında yaşayan 6 milyonu aşkın Türk nüfusunun yaklaşık 5,5 milyonu Batı Avrupa ülkelerinde yaşamaktadır (2018), üçüncü ve dördüncü kuşak olan Türkler kendilerine toplumun çeşitli kademlerinde yer edinmişler hem Türk olmanın hem Avrupalı olmanın avantajlarını kullanmışlardır.

$\mathrm{Bu}$ çerçevede Türk göçmen yönetmenler Türk toplumunda ve yaşadıkları ülkelerde edindikleri deneyimlerini sinemaya aktarırken her iki ülkenin kimliğinin yanı sıra Türkiye ile ilgili hislerini de filmlerine aktarmışlardır. Bu filmlerde geçmişleri ile içinde bulundukları zamanı ele almışlar, Türkiye ile bağ kurmuş ve göç edenlerin hayatlarının algılanmasına dair görüşlerini anlatmaya çalışmışlardır. $\mathrm{Bu}$ tür filmlerin ortak özelliği aileleri ve içinde bulundukları toplumsal çevre ilişkileri bağlamında göçmenlik deneyimleri içerisinde bireylerin üstlendiği rolleri yansıtmalarıdır. Yönetmenler, bu filmlerde ailelerinin göçmenlik deneyimlerini, hayatlarını, geleneksel Türk ailesi içerisinde göçmen olmayı, kültür ve kimlik çatışmalarını, kuşaklar arasındaki kopuşu aktarmaya çalışmaktadır. Özellikle, Alman Türk'ü olarak tanımlanan yönetmenler tarafından çekilen bu türdeki filmler, katıldıkları festivallerde önemli başarılar kazanmış ve kazanmaktadır.

Berlin Sanatlar Akademisi Program Müdürü Johannes Odenthal, Türk kökenli yönetmenlerin sinemaya katkısının büyük olduğunu, bu filmlerin Alman kültürüne yeni bir bakıș açısı getirdiğini ifade etmektedir (Deutsche Welle, 2018). Çünkü sinema, Türk göçmenlerin kendilerini ifade edebilecekleri en etkili araç konumundadır ve her yönetmen yaptıkları filmlerle farklı algılama ve yansıtma biçimlerine sahip olduklarını göstermişlerdir.

Hamburg Güzel Sanatlar Akademisi Sinema Bölümünde eğitim alan Tevfik Başer, 1983 y1lında bu okulun katkısıyla yurt dışında ilk filmini gerçekleştirmiş, Türk işçilerinin kendi yaşamlarını anlatmasından oluşan belgesel film çalışması ile Hamburg'da düzenlenen bir yarışmada teşvik ödülü kazanmıştır. 1987 yılında Locarno Film Festivali’nde gümüş leopar ödülünü aldığı "40 Metrekare Almanya" ve 1988 yılında Strasbourg Avrupa Film Festivalinde büyük ödül aldığı "Sahte Cennete Elveda" filmlerinde geleneksel kimliğe sahip, birinci kuşak Türk göçmenleri ve vatan algılamalarını Türkiye üzerinden aktarmaya çalışmıştır. $\mathrm{Bu}$ filmler ile göçmen Türk kadınını ve erkeğini irdelemiştir.

Almanya'da yaşayan İsmet Erkişi ise ikinci kuşak göçmen olarak, iki film senaryosunun ardından "Son Randevu", "Kısmet" ve "Düğün" filmlerinin yönetmenliğini üstlenmiş ve yurt dışında yaşayan genç kuşağı ve onların çelişkilerini anlatmaya çalışmıştır (Makal, 1994, s.26,114, Sinematurk, 2018).

1990’lı yılların ortalarından sonra ikinci ve üçüncü kuşak Türk göçmenlerin, ulus aşırı kültür fillmleri ile melez kimliğe sahip göçmen gençlerin aileleri içinde kuşaklar arası gerilimi konu alan filmler yapmaya başladıkları görülmektedir. Fatih Akın'ın 1998 yapımı "Kısa ve Acısız" filmi, birinci ve üçüncü kuşak Türk göçmenler arasında yaşanan kopuşu, dinsel ve kültürel kimlik çatışmaları ile anlatmıştır. "Nisan Çocukları" (1998) filmi ile Yüksel Yavuz yine ikinci ve üçüncü kuşak Türk gençlerinin iki kültür arasında gidip gelmeleri ve bu durumun yarattığ sosyal ve psikolojik

\footnotetext{
${ }^{*}$ Bu bölümdeki yönetmen isimleri ve genel bilgiler; Uluslararası Film Festivali Katalogları, Alman Filmleri Türkiye'de (2018), Türk Sineması Veri Taban1, Internet Movie Database, http://www.beyazperde.com, de.wikipedia.org/wiki, ntv.com.tr/news, http://www.hurriyet.com.tr, http://www.berlinturk.com adreslerinden alınmıştır.
} 
yansımaları ele almıştır. Film, Türk gençlerinin içine düştükleri durumu irdelemesi açısından önem taşımaktadır. Thomas Arslan'ın 1999 yılında yönetmenliğini üstlendiği "Satıcı" filmi ise işsiz, eğitimsiz üçüncü kuşak Türklerin yaşam mücadelelerini, Almanya'nın içinde bulunduğu ekonomik ve sosyal krizleri göz ardı etmeden ele almıştır.

$\mathrm{Bu}$ veriler 1şı̆̆ında çalışmanın genel amacı Türk asıllı yönetmenlerin çektikleri filmlerinin ana temalarının ortaya konmasına yöneliktir. Çalışmanın temel hipotezi Türk asıllı yönetmenlerin filmlerinde, göç eden Türklerin, dolayısıyla kendilerinin / ailelerinin hikâyelerini anlatan filmler gerçekleştirdiği yönündedir. Örneklem belirlemede, evreni oluşturan her elemanın örneğe girme şansının eşit olduğu basit tesadüfi örnekleme yöntemi kullanılmıştır. İkinci ve üçüncü kuşak Türk göçmenlerden uzun metrajlı film çeken yirmi üç yönetmenin bilgisine ulaşılmıştır. $\mathrm{Bu}$ yönetmenlerden bir kısmı uluslararası film festivallerinden ödüller kazanmış, bir diğer kısmı ise ulusal ve/veya uluslararası nitelikli festivallerde filmlerini gösterme şansını yakalamışlardır.

Çalışmanın bundan sonraki uzun metraj film çeken Türk asıllı yönetmenlere yer verilerek bu alanda bir literatür oluşturulmaya çalış1lmıştır.*

AKIN, Fatih 1973 yılında Hamburg-Almanya'da Sürmene asıllı Karadenizli bir ailenin çocuğu olarak dünyaya gelen Akın, 2000 yılında Hamburg Devlet Güzel Sanatlar Akademisi Görsel İletişim Bölümü'nden mezun olmuştur. 1995 yılında ilk kısa filmi "Sensin!" (Du bist es!'i) ile Hamburg Uluslararası Kısa Film Festivali’nde izleyici ödülü alan Akın, 1998 yılında ilk uzun metraj denemesi olan "Kısa ve Acısız"1 (Kurz und Schmerzlos) yönetmiştir. Göçmen Türk ailesinin Almanya'da doğup büyümüş oğlu olan Gabriel ve arkadaşlarını konu alan filmde Fatih Akın, farklı kökenlere sahip bireylerin, farklı etnik ortamlardaki ilişkilerini irdelemiştir. Melek isimli bir Türk kızına aşı olan Daniel'in Türkiye'ye uzanan yolculuğunun işlendiği "Temmuz'da" (Juli) filminden sonra üçüncü uzun metraj filmi olan "Solino" (2002) ile Almanya'ya taşınmaya karar veren İtalyan bir aileye odaklanarak, bir aşk hikayesi ile göçmen kültürünü anlatmıştır. Almanya'dan başlayıp İstanbul'a uzanan bir süreçte, Cahit ve Sibel'i anlatan "Duvara Karşı" (2004 - Gegen Die Wand) filmi ile Berlin Film Festivali'nde Altın Ayı ödülünü kazanarak dünya çapında ün kazanan Akın, bu film sayesinde dünya çapında toplam 23 ödüle layık görülmüştür. 2007 tarihli "Yaşamın Kıyısında" filmi Almanya tarafindan, ülkeyi yabancı dilde en iyi film dalında temsil etmek üzere 80. Akademi Ödüllerine gönderilmiş, 60. Cannes Film Festivali'nde En İyi Senaryo dalında ödül almıştır. 2009 yılında yönetmenliğini, senaristliğini ve yapımcılığını üstlendiği "Aşka Ruhunu Kat” (Soul Kitchen) filmi ise 66. Venedik Film Festivalinde jüri özel ödülünü almıştır. 2016 yapımı "Elveda Berlin" (Tschick) ile 14 yaşındaki Maik ile sınıfa yeni gelen göçmen Tschick' in arkadaşlığını kameraya almıştır. Toplamda 14 uzun metraj filmi olan Fatih Akın, 2017 yılında gerçekleştirdiği Türk eşi ve çocuğu neo Nazi saldırısıyla öldürülen bir kadının kendi adaletini sağlama çabasını ve Alman toplumunun ırkçılığa bakış açısını yansıtan "Paramparça" (Aus dem Nichts - In The Fade) filmi ile 2018 yılında düzenlenen 75. Altın Küre’de En İyi Yabancı Film ödülünü almıştır.

\footnotetext{
*Yönetmenler, soyadlarına göre alfabetik olarak sıralanmışlardır.
} 
AKKUŞ, Sinan, Erzincan doğumlu Akkuş, kısa filmlerin ardından 2008 yılında çektiği "Evet, İstiyorum" (Evet, ich will), filminde farklı kültür ve etnik gruplardan gelen ve evlenmek isteyen dört çiftin, önyargılar, kültürel baskılar ve gelenekler ile mücadelesini ele almıştır. Film, Türk kökenli Özlem ile Alman Dirk'ün evlilik isteğine, Özlem'in babasının Dirk'in Müslümanlığa geçmesini şart koyması etrafında evlilik öncesinde yaşanan trajikomik olayları ele almaktadır. Yönetmenin, kültürel farklıkları esprilerle aktarmaya çalıştığı filmde Alman ve Türk oyuncular birlikte rol almışlardır. Film, 2009 yılında Nuremberg Film Festivali’nde En İyi Film, BadenBaden TV Film Festivaline, MFG Star ve 2010 Alman Film Eleștirmenleri Ödüllerine aday gösterilmiştir. Yönetmen, "Üç Türk ve Bir Bebek” (3 Türken und 1 Baby) filmini yine Almanya'da 2015 yılında gerçekleştirmiştir.

ALAKUŞ, Buket, 1971, İstanbul doğumlu Alakuş, ailesinin göç ettiği Almanya'da Berlin Güzel Sanatlar Akademisi'nden 1995 y1lında mezun olduktan sonra Hamburg'da yönetmenlik eğitimi almıştır. 2001 yılında gerçekleştirdiği "Anam” adlı filmi, Münih Film Festivali'nde gösterildikten sonra Oldenburg Film Festivali'nde "En İyi Film" ve 15. Braunschweig Film Festivali'nde Heinrich Ödülü’nü almıştır. Europe Grand Prize'da En İyi Senaryo Ödülü'nü alan film 2002 yılında Max Ophüls Ödülü'ne ve Otto Sprenger Vakfı tarafından En İyi Genç Yönetmen Ödülü’ne layık görülmüştür. Buket Alakuş ilk uzun metraj filmi olan "Anam"da, uyuşturucu bağımlısı oğlunu kazanabilmek için mücadele eden bir annenin öyküsünü anlatmaktadır. "Fin Tangosu" (Finnischer Tango) filmi ile 2008 Alman Film Ödüllerinde Seyirci Ödülü’nü kazanan Alakuş, 2013 y1lında "Acı Soslu Bir Hans” (Einmal Hans mit scharfer Soße) filmini kameraya almıştır. "Die Neue" adlı televizyon filmi ile Avrupa Vatandaşları TV - Kurgu Ödülü (European Civis TV Prize - Fiction)'ne aday gösterilmiştir ve yönetmen televizyon için film yapmaya devam etmektedir.

ARSLAN, Thomas, Alman bir anne ve Türk babanın oğlu olarak 1962 yılında Almanya'da doğmuş, babasının askerlik hizmetini yapmak için geldiği Türkiye'de 1967-1971 yılları arasında Ankara'da yaşamış ve 1971 yılında tekrar Almanya'ya dönmüştür. 19861992 yılları arasında Berlin Film Okulu'nda eğitim alarak, kısa filmlerle yönetmenliğe ilk adımını atmıştır. Filmlerinde Almanya'da yaşayan göçmen Türk gençlerinin hikâyelerine yer veren Arslan, Berlin Üçlemesi olarak tanımlanan "Kardeşler” (1997 Geschwister), "Satıcı" (Dealer 1999), "Güzel Bir Gün” (2001 Der schöne Tag) filmleri ile Alman yeni dalga sinemasının öncülerinden de sayılmaktadır. Yönetmen, "Kardeşler" filminde babaları Türk, anneleri Alman üç kardeşin hikâyesini ele almaktadır. "Satıcı" filmi ise Can'ın uyuş̧turucu satarak hayatını kazanmasını konu almakta, bu çerçevede Almanya'daki göçmenlerin hayatlarından kesitler göstermektedir. Üçlemenin son filmi "Güzel Bir Gün"de film dublörü olarak Berlin'de yaşayan Deniz'in erkek arkadaşından ayrıldıktan sonraki Berlin günlerini konu almaktadır. Arslan, yönetmenliğin yanı sıra senaristliğini de üstlendiği "Satıcı" adlı dramatik filmiyle Berlin Uluslararası Film Festivali'nde FIPRESCI Ödülünü ve Ekümenik Jüri Ödülünü kazanmış, 2013 yılında “Altın" (Gold) adlı filmiyle Berlin Uluslararası Film Festivali'nde Altın Ayı ödülüne ve Puchon Uluslararası Fantastik Film Festivali'nde Puchon'un En İyisi Ödülüne aday olmuştur. Arslan bu filminde, ABD'de altın arayan Alman göçmenlerin hikâyesini konu almıştır. 2017 yılında "Parlak Geceler" (Helle nächte) filmini çeken Arslan, senaristlik ve görüntü yönetmenliği de yapmaktadır. 
ARSLAN, Yılmaz, 1968 doğumlu olan Arslan, sağlık nedenlerinden dolay1 1975'de ailesi ile Almanya'ya göç etmiştir. Fiziksel sakatlığı olan bireylerin tiyatro çalışmaları yaptığı Heidelberg tiyatro grubunda oyunlar yazıp yönetmeye başlamış, 1991 yılında Gramer okulundan mezun olmuştur. 1992 yılında ise Postdam-Babelsberg film okuluna girerek ilk filmi olan "Langer Gang"1 gerçekleştirmiştir. Fiziksel engelli çocuklar ve gençleri konu alan film birçok uluslararası festivalde gösterilmiş ve 40. San Sebastian Festivalinde en iyi film ödülünü almıştır. 1999 yılında ikinci filmi "Yara" ile Max Ophüls Festivali, Saarbrücken, Filmclub - Jüri Ödülü ile Antalya Film Festivali’nde En İyi Film Ödülüne layık görülmüştür. "Kardeș Katili” (Brudermord) 2005 Locarno Film Festivali’nde Gümüş Leopar ödülünü almıştır. Yapımcı, senarist ve yönetmen olarak çalışmalarının yanı sıra, Goethe Institut ağında sinema eğitimi veren Arslan, Medien-und Filmgesellschaft Baden-Wurttemberg (MFG)'nin seçim komitesinin üyesidir. Yönetmen, 2016 yılında Film Maxma adlı yapım şirketini kurmuştur.

AYTEN, Hatice, Essen Yüksek Okulu Fotoğraf ve Film Bölümü’nde eğitim alan Ayten, 1994 yılında ilk filmi "Gülüzar"1 çekmiştir. Filmde, annesinin Almanya'ya göç sürecini konu alarak, kendisinden 15 yaş büyük birisiyle başlık parası karşılığında evlendirilen, birinci kuşak göçmen kadın işçilerinin yeni toplumda yaşadıklarını yansıtmaya çalışmıştır. 1995 yılında Almanya'da doğmuş büyümüş kadınlarla röportajlarının yer aldığ “ "Ohneland” adlı filmini çeken yönetmen 1999 yılında "Merdivendeki İnsanlar" (Menschen auf der Treppe) belgeseli ile 2. Nürnberg Inter Film Festivali, Belgesel Film Yarışmasında finalist olmuştur. "Çayda Şeker Gibi” (Wie Zucker im Tee) adlı uzun metrajlı filmini 2001 yılında tamamlayan Ayten, 2005 yılında gerçekleştirdiği mezuniyet filmi "Mahrem, Kendini Aç" (Mahrem öffne dich) ile İslami kadın hareketinin kadınlara ne getirdiği sorusunu gündeme getirerek, İslam'ın kadına bakış açısıyla değişimini ele almıştır. Almanya'da film yapımcısı olarak adını duyuran ikinci kuşak yönetmenlerden olan Ayten, "Out of Istanbul" filmde de diğerlerinde olduğu gibi dışlanan bireyleri konu almış, 2005 yılında Felix Rexhausen Gazetecilik Ödülü'ne layık görülmüştür. ARTE'de 2011 yılında yayınlanan "Poligam Kadın" (Die polygame Frau) belgeselinde çokeşli Türk erkekleri ve çokeşli yaşayan bir Türk kadını üzerinden çokeşliliği irdelemiştir.

ÇATAK, İlker, 1984, Berlin doğumlu olan Çatak, İstanbul Alman Lisesi’nden mezun olduktan sonra tekrar Berlin'de yaşamaya başlamış, sonrasında burada film ve televizyon yönetmenliği eğitimi almıştır. 2011 yılında Bavyera Radyo Televizyonu'nun burslu sanatçısı olarak ilk uzun metrajlı filmini yazmış, yüksek lisans eğitimini 2014 yılında Hamburg Media School'da tamamlamıştır. "Sadakat" (Fidelity) adlı kısa filmi ile 2015 yılında 42.si düzenlenen Sinema Öğrencileri Oscar Yarışması'nda Yabancı Dilde En İyi Film, Altın Öğrenci Oskar'ına layık görülmüştür. İlk Adım Ödülü ile onurlandırılan Çatak, 2016 yılında ilk uzun metrajlı filmi olan Nils Mohl'un romanından uyarladığı "Bir Zamanlar Kızılderili Ülkesinde" (Es war einmal Indianerland) ile ilk gösterimini Şubat 2017 'de Berlin Film Festivali'nde yapmıştır. Film aynı zamanda 37. IKSV İstanbul Film Festivali'nde "Genç Ustalar" kategorisinde izleyicinin beğenisine sunulmuştur. 
ÇELIKK, Neco, ikinci kuşak yönetmenlerden olan 1972, Berlin doğumlu Çelik, 1994 yılında sinema ile

ilgilenmeye başlamıştır. Berlin'de duvarların yıkılmasından sonra artan ırkçılığa ve düşmanlığına karşı Türk gençlerin oluşturduğu "36 Boys" çetesinin uzun yıllar liderliğini yapmış, sonraki yıllarda bir film şirketi kurmuştur. 2004 yılında ilk uzun metraj çalışması olan "Şehir Gerillaları" (Urban Guerillas) ile Türkiye - Almanya Film Festivali, Seyirci ve Mansiyon ödülünü alan Neco Çelik filmlerinde çok kültürlü ve çok kimlikli bir ortamda yetișen gençlerin hikâyelerini ele almaktadır. Bir diğer uzun metrajlı filmi "Kısık Atește 15 Dakika"nın çekimleri 2006 yılında Türkiye'de gerçekleștirilmiștir. 2011 yılında Stuttgart Operası'nda sahnelediği "Duvara Karșı" filminin opera yorumuyla, Alman tiyatro dünyasının Oscar'ı sayılan Faust'u kazanan ilk Türk olmuştur.

DAĞ, Umut, 1982 Avusturya doğumlu yönetmen Viyana Film Akademisi mezunudur. Michael

Haneke'nin de öğrencisi olan Umut Dağ'ın ilk uzun metrajlı filmi "Kuma" İç Anadolu'nun bir köyünde yaşayan 19 yaşındaki Ayşe'nin altı çocuklu Fatma'nın eşi Hasan'a kuma olarak verilerek Avusturya'nın başkenti Viyana'ya gitmesini ve orada, aile ile yaşadıklarını konu edinmektedir. "Kuma" 2012 yılında Berlin Film Festivali'nin Panorama bölümünün açılış fillmi olarak gösterilmiştir. 2011 yılında "Papa" adlı filmi gerçekleştiren Dağ, Almanca eğitim veren sinema yüksekokullarının mezunlarına verilen First Steps Ödülü’nü kazanmıştır. Hapisten yeni çıkmış olan Ertan ile Viyana sokaklarında ve gece kulüplerinde uyuşturucu satan oğlu Mikail karakterleri üzerinden sorunlu aile ilişkilerini ele alan ikinci uzun metrajı "Betondaki Çatlaklar" (Cracks in the Concrete) filmi yine 2014 y1lında ilk gösterimini Berlin Film Festivali’nde gerçekleştirmiştir. 2016 yılında "Olay Yeri: Rebecca" (Tatort: Rebecca) adlı televizyon filmini çeken Dağ, 2017 y1lında "Alman Çocuk" (Das deutsche Kind) adlı filmin yönetmenliğini üstlenmiştir. Dağ, bu filmi ile Alman ve Türk kültürünü birlikte yaşayan üç kişilik bir ailenin, ölen Alman arkadaşlarının kızının velayetini alma mücadelesini, inanç, aile ve vatan gibi değerler bağlamında anlatmaktadır. Alman ve Hristiyan bir çocuk ile Türk ve Müslüman aile karşıtlığını başarılı bir şekilde ele alan yönetmen bazı sinema eleştirmenleri tarafından Avusturya'nın Fatih Akın'ı olarak görülmektedir.

Derin, Seyhan, 1967, Zonguldak, doğumlu olan yönetmen 5 yaşında ailesiyle birlikte Almanya'ya göç

etmiştir.1991-1997 yıllarında Münih Tv ve Film Okulu, Drama Bölümünde yönetmenlik ve senaryo yazarlığı eğitimi almıştır. Derin, genelde göç konulu kısa filmler çekmiş, 2002 yılında ise "Yıldızlar Arasında" (Zwischen den Sternen) adlı ilk sinema filmini gerçekleştirmiştir. Bu film ile Max Ophüls Ödülü'ne aday gösterilmiştir. Yine 2002 y1lında "İyi Günler Kötü Zamanlar" (Gute Zeiten Schlechte Zeiten) filmini kameraya almıştır. Diğer önemli çalışmaları "Midede Kelebekler" (2006- Schmetterlinge im Bauch), Anna ve Aşk (2008- Anna \& die Liebe), "Veda Veda" (2008- Abschied vom Tod), "Herkes İçin Bir" (2009- Eine für alle), "Kimseye Benzemeyen Biri" (2010- Eine wie keine), "Mutluluğun Yolları" (2012- Wege zum Glück), "Yasak Aşk" (2013- Verbotene Liebe) filmleridir. Seyhan Derin'in çalışmalarında Türk - Alman kültürü ekseninde geçişler, ulusal sınırlara dayanan kültürel anlaşmalar ve kuşaklar arası çatışmalar tartışılmaktadır. Özellikle 1996 yılında mezuniyet projesi olarak gerçekleştirdiği "Ben Annemin Kızıyım” (Ich bin 
Tochter meiner Mutter) adlı belgesel filmi ile Osmanlı kültürü ile yetişmiş anneanne, Türkiye'de doğup büyümüş ve evlendikten sonra çocuklarıyla işçi kocasının ardından Almanya'ya göç etmiş bir anne ve babasının tekrar Türkiye'ye anneannesinin yanına gönderme isteğine rağmen Almanya' da kalan 16 yaşındaki genç bir kızın hikayesini irdelemiş ve büyük beğeni kazanmıştır.

ERGÜVEN, Deniz Gamze, 1978 Ankara doğumlu olan Ergüven, 6 aylıkken ailesi ile Fransa'ya göç etmiştir. Paris Üniversitesi'nde Edebiyat ve Afrika Tarihi okuduktan sonra Güney Afrika'da Johannesburg'da yüksek lisans eğitimini tamamlamış, 2002 yılında Fransa'nın en önemli sinema okullarından La Fémis'te yönetmenlik eğitimi almaya başlamıștır. 2006 yılında bitirme projesi olarak gerçekleștirdiği "Bir Damla Su" (Une Goutte D'eau) isimli kısa filmiyle Cannes Film Festivali'nde yarışmıştır. Kültürel olarak Fransız hissettiğini ancak hikâyelerinde Türkiye'yi anlatmayı hedeflediğini ifade eden yönetmen ilk uzun metraj çalışması olan "Mustang" adlı filminde Türkiye'den bir hikâyeyi, beş kız kardeşin aile ve toplumun baskısıyla yüzleşmesini, tamamen Türkçe anlatmasına rağmen 88. Akademi Ödülleri'nde Yabancı Dilde En İyi Film Akademi Ödülü için Fransa'nın adayı olarak yarışmıştır. Bu film ile Cannes'da 'Europa Cinemas Label' ödülünü, Odesa'da 'Büyük Ödül'ü ve En İyi Yönetmen ödülünü, Saraybosna Film Festivali ve 10. Roma Film Festivali’nde En İyi Film ödülünü, İspanya 60.Uluslararası Seminci Film Festivali -en iyi 2'nci filme verilen "Gümüş Başak" ödülünü kazanmıştır. 2017 yılında senaristliğini ve yönetmenliğini yaptığı başrollerini Halle Berry ve Daniel Craig paylaştığ 1 , "Kings" filmiyle, tarihte ' 1992 Los Angeles Olayları' olarak adlandırılan, taksi şoförlüğü yaparken Los Angeles polisi tarafindan darp edilen siyahi Amerikan vatandaşı Rodney King'i darp eden polislerin serbest bırakılmasıyla başlayan olayları ve bu olaylar birlikte başlayan protestoların ortasında kalan bir ailenin mücadelesini anlatmıştır.

GÖKALP, Matthias, 1973 doğumlu Gökalp, Paris'te modern edebiyat eğitimi aldıktan sonra Belçika INSAS'da eğitim almıştır. Senaristlik ve yönetmenlik yapan Gökalp, Paris'teki Latin Mahallesi'nde bir sinema tiyatrosu işletmecisi olan babaannesi sayesinde sinemaya merak salmıştır. 1991 y1lında "Kromatik" (Chromatiques), 2001 yılında "Yarı" (MiTemps), 2002 yılında "Tanrı'nın Fiyatı" (Le tarif de dieu) ve 2004 yılında ise "Düz ve Dar" (The Straight And Narrow) adlı kısa filmleri yönetmiştir. İlk uzun metrajlı filmi "Kişisel Bir Şey" (Rien de personnel)'i 2009 yılında gerçekleştirmiştir. İş dünyasını farklı bir dil ile ele alan film Cannes Film Festivali'nde Eleştirmenler Haftasında gösterilmiştir.

IŞSiTMEZ, Müret, 1979'da Strasbourg'da, göçmen bir ailenin sekizinci çocuğu olarak dünyaya gelen

İşitmez, Paris'te sinema eğitimi 20 yaşında Denis Diderot Üniversitesi’nden ESRA Sinema Okulu'ndan sertifika almıştır. İlk uzun metraj çalışması 1970'li yıllarda Fransa'ya göçen ailesinin hikayesini anlattı̆̆ 1 "Annem ve Babam" (Ma Mere Et Mon Pere) belgeselini 2015 yılında gerçekleştirmiştir. Yönetmen, filminin Fransa'ya Türk göçünü ele alan ilk belgesel olduğunu vurgulamaktadır. 
KARAMAN, Onur, Montreal'de yaşayan Türk yönetmenin ilk uzun metraj çalışması olan "İnsan Çiftliği” (La ferme des humains) 2013 yılında SODEC (Kültürel Girişim Geliştirme Şirketi) tarafindan desteklenmiş ve Yeni Sinema Festivali (Festival du Nouveau Cinéma)'nde gösterilmiştir. 2015 yılında Quebec'li bir aile tarafından evlatlık alınmış Atilla'nın, Türk köklerini keşfetme hikayesini konu alan “Atilla'nın Geçtiği Yer" (La ou Atilla Passe) filminin galası Kanada'da, Uluslararas1 AbitibiTemiscamingue Film Festivali'nde yapılmıștır. Türk kültürüne ve sinemasına hizmet etmek amacıyla Türk sinemasının 100. yılında Altın Boynuz Türk Film Șenliği'ni, Montreal'de organize eden Onur Karaman sinema eğitimini de burada tamamlamıştır.

KUTLUCAN, Hussi, 1962 Kemah doğumlu olan Kutlucan, Almanya' da büyümüş çeşitli filmlerin senaristliğini, yönetmenliğini üstlenmiş, oyunculuk yapmıştır. 1991 yılında komedi türünde ilk uzun metraj çalışması olan "Mezra'da Yaz" (Sommer in Mezra) filmini gerçekleştirmiştir. 1998 y1lında ise "Ben Baş Siz Ayak" (Ich Chef, Du Turnschuh) filminde Ermeni bir sığınmacının çalışmak üzere Berlin'e gitmesini ele almıştır.

KÖKTEN, Sümeya, Afyonkarahisarlı bir ailenin beş çocuğundan en küçüğü olan Kökten, 1980, Belçika doğumludur. Asıl mesleği polislik olan Sümeya Kökten 2008 yılında senaryosunu yazdığı "Yasak Hisler" (Sens İnterdits) filminin yapımcılığııı ve yönetmenliğini üstlenmiştir. Film, biri Türk olan eşcinsel çiftin ilişkisini ele almaktadır. İkinci filmini 2011 yılında Belçika Kültür Bakanlığı' nın desteğiyle "Gizli Yüzler" (Faces cachées) adlı filme çekmiştir. 2015 yıllında ise "Son Bir Dans" ile "Vesvese: Cin Tuzağı" filmlerini Türkiye'de gerçekleştirmiştir. Filmlerinde kadınerkek ilişkileri ekseninde karakterlerin ruhsal durumlarına değinmekte ve psikolojik gerilimi işlemektedir. Vesvese: Cin Tuzağı ile ilk Türk kadın korku filmi yönetmeni olarak adından ayrıca söz ettirmiştir.

POLAT, Ayşe, 1970 Malatya doğumlu olan Polat, 1978'de ailesi ile Almanya'ya göç etmiştir. Berlin ve Bremen üniversitelerinde felsefe, sanat ve edebiyat eğitimi alan yönetmen ilk yıllarda özellikle dördüncü kuşak toplumun sorunlarını içeren kısa filmler çekmiştir. 1992'de intihar eden Türk asıllı bir ilticacının hayatının anlatıldığı ilk kısa filmi "Yabancı Gece" (Fremdnacht) ve 1997 yılında çektiği "Beyhan İçin Bir Eğlence" (Ein Fest für Beyhan) filmleri birçok film festivalinde gösterilmiştir. İlk uzun metrajlı filmi "Yabancı Tur" (Auslandstournee) da Türk babasını henüz kaybetmiş olan on bir yaşındaki kız çocuğunun Türk kabare şarkıcısı ile onu doğumda terk eden annesini Avrupa'yı gezerek aramalarını konu almaktadır. 2004 yılında çektiği ikinci filmi "Bekçi" (En Garde) ile Locarno Uluslararası Film Festivali'nde ve Alman Film Eleştirmenleri Ödüllerinde En İyi Film ödüllerini almıştır. 2010 yapımı "Mutluluk Lüksü” (Luks Glück) ve 2013 yapımı "Mirasçı" (Die Erbin) filmlerinin çekimlerini Türkiye ve Almanya'da gerçekleştirmiştir. 2015 y1lında ise “Ötekiler” belgeseli 35. İstanbul Uluslararası Film Festivali, Ulusal Belgesel Yarışması, Finalist olmuştur. 
SAMDERELİ, Yasemin, 1959 yılında Tunceli'den Almanya'ya çalışmak için giden ilk işçi ailelerinden

birinin çocuğu olan Samdereli 1973 yılında Dortmund şehrinde doğmuştur. Televizyon filmleri ve kısa film çalışmaları olan yönetmen, 2011 yılında gerçekleştirdiği “Almanya'ya Hoş Geldiniz" (Welcome To Germany) filmi ile üç kuşak göçmen Türk ailesini konu almış ve 61. Alman Film Ödülleri töreninde en iyi senaryo dalında "Altın Lola", 61. Berlin Film Festivali'nde (Berlinale) "Gümüş Lola” ödülünü ve 48. Altın Portakal Film Festivali'nde uluslararası uzun metraj jüri özel ödülünü almıştır. 2018 yılında “Gecelerin Gecesi” (Die Nacht der Nächte) adlı belgesel çalışmasında ise geleneksel bir düğün gecesini anlatmıştır.

TABAK, Hüseyin 1981 Lemgo, Almanya doğumlu olan Tabak, Kahramanmaraşlı bir ailenin çocuğudur. Genç yaşta film setlerinde çalışan ve kısa filmler çeken yönetmen 2006'da Viyana Film Akademisi'nde rejisörlük ve senaryo okumaya başlamıştır. 2008 yılında "Ev" (Heim) ve "Peynir" (Cheeese) adlı kısa filmleriyle birçok ödül almıştır. Uzun metrajlı belgesel çalışması olan "Başla" (Kick Off) Avusturya'nın Steiermark Eyaleti’nin Diagonale Gençlik Jüri Ödülü ve İzleyici Ödülü ile Viennale Belgesel Ödülü’ne layık görülmüştür. "Güzelliğin On Par' Etmez” (Deine Schönheit ist nichts wert) Avusturya'ya göç eden bir ailenin yeni ülke, yeni dil ve yeni kültür ile topluma uyum çabalarını evin küçük oğlu ekseninde ele alan film 49. Antalya Altın Portakal Film Festivali'nde birçok ödül almıştır. 2017 yılında gerçekleştirdiği "Çirkin Kral Efsanesi" (The Legend of the Ugly King) belgeseli dünya prömiyerini Y1lmaz Güney'in 33. ölüm y1l dönümünde Toronto Film Festivali'nde gerçekleştirmiştir. Yönetmen bu çalışması ile de birçok ödül kazanmıştır.

ÜCE, Volkan, Türk asıllı Belçika doğumlu Üce, siyasal bilimler eğitimi almıştır. Belçika ve Hollanda'da büyüyen Üce, 2017 Belçika yapımı olan ve kendi gibi Belçika ve Hollanda'da büyüyen üçüncü nesil Türklerin kimlik krizini anlatan ilk uzun metrajlı belgesel çalışması Arafta (Displaced) ile 2017 TRT Belgesel Ödülünü almıştır. Belgesel aynı zamanda 11. Documentarist İstanbul Belgesel Günleri, Türkiye Panorama Bölümünde ve 17. İF İstanbul Uluslararası Bağımsız Filmler Festivali gösterim seçkisinde gösterilmiştir.

YAPICIOĞLU, Mennan, 1966 yılında Münih'te doğmuştur. 1988'de, bazı Alman dağıtım şirketlerinin

pazarlama bölümünde çalışarak film hayatına başlamıştır. 1995'de İngilizce ve Almanca senaryolar yazmış ve kısa filmler çekmiştir. Elveda Lenin (Good Bye Lenin 2003) ve "Tual Bedenler" (The Pillow Book 1996) filmlerinde oyunculuk yapan, "After Hours" ve "Lautlos" (Sessiz) filmlerinin senaryolarını da yazan yönetmen, 1999 yılında, 30 değişik film festivaline konuk olan "Framed" adlı ilk kısa metrajlı filmiyle Almanya'da "En İyi Kısa Film" ödülüne aday gösterilmiştir. Yapıcıŏlu, 2004 yılında Almanya'da çektiği bir kiralık katilin hikâyesini konu alan ilk uzun metrajlı filmi Sessizce (Lautlos) ile dikkatleri üzerine çekmeyi başarmış ve sonrasında film çalışmalarını Hollywood'da devam etmeye karar vermiştir. Sandra Bullock'un başrolünü oynadığı 'Sıradışı' (Premonition) filmini 2007 yılında Amerika'da gerçekleştirmiştir. 
YAVUZ, Yüksel, 1964'te Elâzığ il merkezine bağlı Karakoçan'da doğan Yavuz, 1980 yılında

Almanya'da yaşayan babasının yanına gitmiştir. Üçüncü kuşak genç Türk yönetmenlerden Yüksel Yavuzu, 1986 yılında Hamburg'da Ekonomi ve Sosyoloji eğitiminin ardından 1992-1996 yılları arasında, Hamburg Güzel Sanatlar Akademisi'nde görsel iletişim alanında okumuştur. 1994 yapımı "Misafir İşçi Babam" (Mein Vater, der Gastarbeiter) adlı belgeselinde büyük oranda kendi hayatından ve ailesinin geçmişinden esinlenmiştir. 1998 yllında ilk uzun metraj filmi "Nisan Çocukları" (April Kinder) filminin ardından birçok kısa film çekmiștir. 2003 yılında "Küçük Özgürlük" (A Little Bit Of Freedom), 2010'da "İstanbul İçin Özlem" (Sehnsucht nach Istanbul), 2013 yilında "Umut" (Hoffnung) belgesellerini gerçekleştirmiştir.

"Küçük Özgürlük", 2003 yılında 15. Ankara Film Festivali'nde En İyi Film, 2004 yılında ise 23. İstanbul Film Festivali’nde Halk Jürisi En İyi Film ödülünü almıştır. Film aynı zamanda 2003 y1lında Cannes Film Festivalinde Quinzane Des Realisateurs Bölümünde gösterilmiştir. "Küçük Özgürlük" Almanya'da kaçak göçmen olan iki gencin arasındaki dostluğa ele almaktadır. Almanya'da kaçak olarak yaşayan, ailesini kaybetmiş Baran kendi gibi kaçak olarak yaşayan Chernor ile tanışır. Chernor, bir Afrikalıdır ve en büyük hayali Avusturalya'ya gitmektir ve bunun için paraya ihtiyacı vardır. Bu ihtiyacı için uyuşturucu işine girmiștir. Film, eleştirmenlerce göçmen sorununa içeriden ve gerçekçi bir gözle bakmayı başaran, etkileyici bir çalışma olarak değerlendirilmektedir.

YILDIRIM, Özgür, 1979 Dulsberg doğumlu Yıldırım'ın ailesi 1960'larda Almanya'ya göç etmiştir. Hamburg Film Akademisi mezun olan yönetmen ilk kısa metrajlı filmi "Alims Markt" ile büyük beğeni toplayarak uzun metraj film projesi "Chiko" için Alman Film Teşvik Dairesi tarafından 325 bin Euro ile en yüksek teşvike layık görülmüştür. 2008 yılında gerçekleştirdiği ilk uzun metrajı "Chiko" filmini yazıp yöneten Yıldırım bu çalışmasında Hamburg'un kenar mahallelerinde yaşayan Chiko ve Tibet adlı iki Türk gencinin hayatını; uyuşturucu satıcısı Brownie ile tanışmalarıyla değişen yaşamlarını anlatmaktadır. Yönetmen 2012 yılında "Blutzbrüdaz", 2015 yılında ise "Boy 7" ve 2017 yılında "Sadece Tanrı Beni Yargilayabilir" (Nur Gott kann mich richten) filmlerini çekmiştir.

İkincil kaynaklara bağlı olarak yapılan araştırmada ikinci ve üçüncü kuşak Türk göçmenlerden uzun metraj film çeken, ulusal ve/veya uluslararası film festivallerinde ismini duyuran yirmi üç yönetmenin bilgisine ulaşılmıştır. Bu yönetmenlerin filmlerinden bir kısmı gösteri seçkisi ya da özel gösterimlerde izleyici ile buluştuğundan filmlerin tamamı izlenememiş, tanıtım filmleri, film özetleri, eleştirmen yorumlarından faydalanılmıştır.

Yukarıda yer verilen yönetmenlerden on dördü uzun metraj filmlerinde kendilerinin, ailelerinin ve arkadaşlarının hikâyesinden yola çıkarak göç olgusunu işlemişlerdir. Kısa film çalışmalarında da ele alınan göç konusu, yönetmenlerin tüm film çalışmalarında görülmemektedir. Birinci kuşak Türk asıllı yönetmenlerin aksine ikinci ve üçüncü kuşak yönetmenler göç olgusu ile sınırlı kalmayarak sinemanın beslendiği diğer konulara da değinmişler, farklı kültürleri yeni hikâyeleri ele alan filmler gerçekleştirmişlerdir.

Deniz Gamze Ergüven, Thomas Arslan, Mennan Yapıcıŏ̆lu gibi yönetmenler çalışmalarını Avrupa ile sınırlamamış, Amerika'ya uzanmışlardır. Örneğin, Thomas Arslan, Almanya'daki 
göçmenlerin hayatlarından kesitler sunduğu ilk filmlerinin ardından, 1898 yılında Kuzey Amerika'da altın arayan bir grup Alman göçmenin hikâyesini ele alan "Altın" filmini 2013 yılında gerçekleştirmiştir. Deniz Gamze Ergüven ise "1992 Los Angeles Olayları" olarak adlandırılan, taksi şoförlügü yaparken Los Angeles polisi tarafından darp edilen siyahi Amerikan vatandaşı Rodney King' in hikâyesini izleyici ile buluşturmuştur. Sandra Bullock'un başrolünü oynadığı "Sıradışı" filmi Amerika'da Mennan Yapıcıoğlu tarafindan gerçekleștirmiștir. "Duvara Karșı" filmi ile dünya çapında ün kazanan Fatih Akın, on iki yönetmenle birlikte New York'un beş ayrı bölgesinde gerçekleştirilen "Seni Seviyorum New York" (2008) filminde yönetmenlik yapmıştır.

\section{Sonuç Yerine}

Avrupa Göçmen Sineması ve Türk asıllı yönetmenlerin ele alındığı bu çalışmada yirmi üç yönetmenin özgeçmişi ve uzun metraj film çalışmaları irdelenmiş, tanıtım filmleri, film özetleri, eleştirmen yorumlarından faydalanılmış, ulaşılabilen filmler izlenmiştir.

Toplumların, tarihinden ve kültüründen ayrı ele alınması mümkün olamayan sinema filmleri, içinde gerçekleştiği toplumsal koşulların yansıtıldığı, en net anlaşılabilen, sanat ürünleridir. İnsanlara özgür, rahat bir hayat vaat eden Batı Avrupa ülkeleri özellikle imkânsılılılar yüzünden göç etmek durumunda kalan Türk işçilerinin ve onların çocukları için güzel, güzel olduğu kadar da zor bir hayatı ifade etmektedir. Göçmenlere karşı gösterilen negatif tutum, göçmenlerin kendi içlerinde yaşadıkları sorunlar sinema sanatının incelikleri ile beyaz perdeye göç olgusunun tam ortasında kalan kuşaklar tarafindan yansitılmış ve yansitılmaktadır.

Türk asıllı yönetmenlerin filmografileri incelendiğinde, özellikle Avrupa'ya göç eden ilk kuşak ailelerin çocukları ve onlardan sonraki kuşakların sinemayı yaşadıkları ya da şahit oldukları göç olgusu ve etkilerini aktarmak için kullanmışlardır. İnsanların duygularına dokunan, düşündüren, kendini sorgulamasına neden olan kavramları canlandırmak ve belki de tepki üretmek amacı ile filmler çeken Türk asıllı yönetmenler ilk filmlerini yaşadıkları ülkede gerçekleştirmişlerdir. Bununla birlikte yönetmenlerin Naficy'nin de yukarda değinilen tanımına uygun olarak çok dilli filmler ürettikleri görülmektedir.

Kurmacanın yanı sıra belgesel filmler üreten yönetmenler göç olgusunu ele aldıkları filmlerinde yakın çevrelerinin ve kendilerinin yaşam deneyimlerinden faydalanmışlardır. Filmleri festivallerde gösterilen ve birçok ödül alan yönetmenlerden daha genç nesillerin sonraki yapımlarında konu olarak göç olgusundan uzaklaştıkları da ayrıca göze çarpmaktadır. Sinema alanında eğitim almış olan yönetmenler bulundukları ülkenin şartlarından faydalanmakta kimi zaman festivallerde o ülkeler adına yarışmaktadırlar. Türkiye' deki bilinirlikleri ise film festivalleri ya da aldıkları ödüller sayesinde gerçekleşmektedir.

Günümüzde göçlerin, serbest göç olarak tanımlanan, bireylerin kendi tercihleriyle gerçekleştirdiği bir eylem olmasından ötürü bu alt türe giren filmler aracılığıyla yönetmenler yaşadıkları toplumlarda farkındalık yaratmışlar ve dikkat çekmişlerdir. Örneğin; Üniversite eğitimi için Roma'ya giden, İstanbul doğumlu yönetmen, senarist ve oyuncu Ferzan Özpetek'in İspanya, İtalya ve Türkiye arasında geçen 1997 yapımı "Hamam" filmi Cannes Film Festivalinin bir bölümü olan 'Quinzaine des Réalisateurs'de yer almış, "Harem Suare” filmi 1999 yılında Cannes Film Festivali'nde 'Un Certain Regard' kategorisinde gösterime girerek Londra Film Festivali ve Toronto Film Festivaline davet edilmiştir. 2009 yılında çektiği "Serseri Mayınlar" filmi ise Los Angeles Film Festivali aç11ışındaki gösterilmiştir. 
William Petersen'ın da değindiği gibi göçün tipleri vardır ve insanlar şiddetten, baskıdan kurtulmak ya da daha iyi bir hayat yaşamak için doğduğu ülkeden ayrılmak zorunda kalmakta ya da ayrılmayı tercih etmektedir. Gittikleri yerlerde de doğal, ekonomik, siyasal vb. zorunluluklar sonucunda yaşadıklarının etkisinde kalan, hissettiklerini sinema aracılığıyla aktarmak isteyen yönetmenlerin konu tercihleri de bu bağlamda, göç nedenlerine göre, farklılıklar göstermektedir.

Genel olarak değerlendirildiğinde Türk asıllı yönetmenlerden zorlu şartlarda ülkesinde ayrılmak zorunda kalan ve göç ettiği ülkede sıkıntılar yaşayanlar göçün etkilerini ele alırken özgür tercihi ile ülkesini değiştiren ve sosyo-ekonomik durumu standart şartlarda olan yönetmenlerin genel toplumsal konulara filmlerinde değindikleri de görülmektedir.

\section{Kaynakça}

Abadan-Unat N. (2002), Bitmeyen göç: konuk isçilikten ulus-ötesi yurttaşlı̆̆a. İstanbul: İstanbul Bilgi Üniversitesi Yayınları.

Akbulut, H. (2001), "Ulus-Aşırı Türk Sinemasında Kimlik Anlayışları: Fatih Akın ve Yüksel Yavuz Sineması”, Kimlik, Medya ve Temsil, der. E. B. Akça, Nobel Yayınları, Ankara.

Akbulut, H. (2003), "Sinemanın Medeniyet Halleri: Türk Sinemasında Kimlik, Medeniyet ve Modernleşme Temsilleri”, Düşünen Siyaset.

Anderson, B. (2004), Hayali Cemaatler: Milliyetçiliğin Kökenleri ve Yayılması. (Çev. İskender Savaşır), Metis Yayınları, İstanbul.

Armutçu, E. (2004), ‘'Iki Ülkeye Birden Hasret Kaldıkları Ödülü Getiren Türk’, Hürriyet Gazetesi.

Başaran, F. (1972), “Türkiye'de Beyin Göçü Sorunu”, http://dergiler.ankara.edu.tr/dergiler/34/970/11940.pdf. Erişim Tarihi: 17.03.2018

Bazin, A. (1993). Sinema Nedir? (Çev. İbrahim Şener) Sistem Yayınları, İstanbul

Berger, J. (2011), Yedinci Adam, (Çev. Cevat Çapan) Agora Kitaplı̆̆ı, İstanbul

Bilis, Ö. P. (2004) 'Doksanlı Yıllar Sonrası Alman Sinemasında Türk

Temsilleri’, Yayımlanmamış Yüksek Lisans Tezi, Ege Üniversitesi Sosyal Bilimler Enstitüsü,

Crisp, J. (2006), "Policy Challenges of the New Diasporas: Migrant Networks and Their Impact on Asylum Flows and Regimes"

http://www.transcomm.ox.ac.uk/working\%20papers/riia3.pdf, 
Erişim Tarihi: 14.01 .2018

Çoban, Ç. (2014), Uluslararası Göçün Kent Üzerindeki Etkilerinin Sinemada Temsili: TürkiyeAlmanya Örneği İstanbul Teknik Üniversitesi, Fen Bilimleri Enstitüsü

Durugönül, E.(2002), “Göç Yolları”, Görüş, (Haziran)

Eren, M. (2003), Traveling pictures from a Turkish Daughter Seyhan Derin's Ben Annemin Kızıyım Moving Pictures, Migrating Identities Eva Rueschmann Univ. Press of Mississippi,

Göktürk, D. (1999), "Turkish Woman on German Streets: Closure and exposure in Transnational Cinema" Spacek in European Cinema, Intellect Books, Bristol

Göktürk, D. (2005) 'Migrant İdentities in Transnational Cinema'” www.transcomm.ox.ac.uk/working, Erişim Tarihi: 14.01.2018

Güzel, C. (2001) Sömürgeci Söylem ve Sinema: Kültürel Yanlılığın Sunumu. Türk Film Araştırmalarında Yeni Yönelimler 1. Bilim ve Sanat Yayınları, İstanbul

Iş1koğlu, D. (2005). Kültürlerin Kesişimi, Aksanlı Sinema ve Almanya'daki 2. ve 3. Kuşak Türk Yönetmenlerin Sinemasal Üretimi. (Yayımlanmamış Yüksek Lisans Tezi). İstanbul Üniversitesi Sosyal Bilimler Enstitüsü, İstanbul

İçduygu, A. (2006), "A Panaroma of the International Migration Regime in Turkey", Revue Européenne des Migrations Internationales,

https://journals.openedition.org/remi/3221, Erişim Tarihi: 10.02.2018

Kablamacı, M. D. (2013) Gurbet Ne Yana Düşer: Suyun Öte Yanına Kadın Araştırmaları Dergisi, Sayı 12,

Kanbur, A. (2005) 'GGöçmenliğin Gölgesinde', Toplumbilim Dergisi, Sayı: 18

Keeley, B.(2009). "Internationale Migration - die menschliche Seite der Globalisierung". OECD Publications: Paris. http://www.oecd.org/document/28/0,3746, Erişim Tarihi: 17.03.2018

Kolker, R. P. (1999) Yalnızlık Sineması. (Çev. Ertan Yılmaz) Öteki Yayınları, İstanbul

Löwisch, H. (1998), Interview with Seyhan Derin: Ben Annemin kızıyım, Triangulated Visions: Women in Recent German Cinema Editör: Ingeborg Majer O'Sickey, Ingeborg von Zadow State University of New York Press

Makal, O. (1994), Sinemada Yedinci Adam: Türk Sinemasında İç ve Dış Göç Olayı, Ege Yayıncılık, İzmir 
Massey D. S, Arango J., Hugo G., Kouaouci A., Pellegrino A., Taylor J E. (1993) Theories of International Migration: A Review and Appraisal. Population and Development Review.http://citeseerx.ist.psu.edu/viewdoc/download?doi=10.1.1.667.4527\&rep=rep1\&type $=$ pdf Erişim Tarihi: 05.02.2018

Monkachi, N. (2003) 'Göç Sosyolojisini Yeniden Düşünmek', (Çeviren Enes Kabakçı),Toplumbilim Dergisi, Sayı: 17

Naficy, H. (1995). 'Phobic spaces and liminal panics: Independent Transnational Film Genre'. Suitcase, No:1\&2.

https://www.academia.edu/11053114/_Phobic_Spaces_and_Liminal_Panics_Independent_Transnat ional_Film_Genre_Erişim Tarihi: 05.02.2018

Naficy, H. (2001), An Accented Cinema: Exilic and Diasporic Filmmaking. Princeton University Press, New Jersey

Odabaş, B. (2013), Üçüncü Sinema, Agora Kitaplığı, İstanbul

Rotha, P.(1968), "Belge Filmciliğinin Bazı İlkeleri”, Türk Dili Dergisi, Sinema Özel Sayısı, Arsal Soley (çev.), Ocak (196): 341-343, Ankara Üniversitesi Basımevi, Ankara.

Rotha, P. ve Griffith, R. (2001), Sinema Yazıları. (Çev. Ayzer Ovatman) İzdüşüm Yayınları, İstanbul

Tekeli, İ. (2008), Göç ve Ötesi, Tarih Vakfı Yurt Yayınları, İstanbul

Teksoy, R. (2005) Dünya Sinema Tarihi Oğlak Yayınları, İstanbul

Tosun, A. F. (2006). Almanya'da Yaşayan Türk Yönetmenlerin Filminde Göçmenlik Olgusu. (Yayımlanmamış Yüksek Lisans Tezi). Dokuz Eylül Üniversitesi Güzel Sanatlar Enstitüsü, İzmir

Turan, K. (1997), Almanya'da Türk Olmak Başbakanlık Aile Araştırma Kurumu Başkanlığ Yayınları, Ankara

Ünver, C. (2010), Türkiye'nin Göç Siyasetinin Temel İlkelerine İlişkin Yeni Yaklaşımlar: Göç Araştırmaları, www.turksam.org, Erişim Tarihi 12.11.2017

Vincenti, G. (2008), Sinemanın Yüzyılı, Evrensel Yayınları İstanbul

Yalçın, C. (2004), Göç Sosyolojisi, Anı Yayıncılık, Ankara

Yaren, Ö. (2015), Göçmen Sinemasını Yeniden Düşünmek, Moment Dergisi,

http://dergipark.gov.tr/ 
Yumul, A. (2000), "Modernizmden Postmodernizme Ötekilik", Karizma Dergisi, Say1: 3, (2014) "Migrant and Diasporic Cinema in Contemporary Europe" http://www.migrantcinema.net/glossary/term/accented_cinema/Erişim Tarihi 05.02.2018

Alman Filmleri Türkiye'de

Uluslararası Film Festivali Katalogları,

Türk Sineması Veri Tabanı,

Internet Movie Database,

http://www.beyazperde.com,

http://www.berlinturk.com

http://www.dw.com,

http://www.de.wikipedia.org/wiki,

http://www.mfa.gov.tr

http://www.ntv.com.tr/news,

http://www.hurriyet.com.tr,

http://www.tdk.gov.tr 